\title{
Research on the Impact of Social Credit Improvement on the Debt Financing of Agricultural Enterprises
}

\author{
Hang Cheng* \\ Yunnan University of Finance and Economics, Kunming 650221, China \\ *Corresponding author: Hang Cheng, 1506440232@qq.com
}

\begin{abstract}
This study takes China's A-shares agricultural companies as the research subjects and examines the influence of social credit environment on the debt financing of agricultural enterprises. This study has found that the improvement of social credit environment can significantly increase the debt financing scale of agricultural enterprises. After a placebo test, the replacement of explained variables, and the control of industry fixed effects, the results obtained are still significant. The mechanism test found that the scale of the enterprise has a complete intermediary effect; that is, the social credit environment can increase the scale of external financing of agricultural enterprises by increasing the scale of the enterprise. This article focuses on the impact of informal institutions on corporate debt financing, which is conducive to enriching relevant research on agricultural enterprises and has important practical significance for promoting the development of the agricultural industrial chain as well as "village revitalization."
\end{abstract}

Keywords: Social credit; Debt financing; Agricultural enterprise; Village revitalization

Publication date: December 2021; Online publication: December 31, 2021

\section{Introduction}

Agricultural enterprises carry the hope of rural revitalization. Developing agricultural enterprises has become an important part of "rural revitalization." In China's credit market, credit discrimination is widespread. Private enterprises in China lack guarantees and mortgages, and banks are unwilling to lend, causing credit discrimination. In this environment of credit discrimination, private enterprises rely more on the support of informal systems. Hence, discussing the impact of social credit environment on debt financing among agricultural enterprises appears to be of practical significance.

Current literatures on corporate debt financing are mostly based on corporate characteristics and other aspects. Some scholars have studied the impact of corporate size on corporate debt financing ${ }^{[1]}$. Other scholars have also studied the impact of corporate profitability on corporate debt financing ${ }^{[1,2]}$. In addition to the size of the company and the profitability of the company, Wang Haofi and another scholar have proposed that the higher the pledge ratio of major shareholders, the more difficult the debt financing of a company ${ }^{[3]}$. It has also been mentioned in another study that the better the media reputation of a company, the more the company's loans would increase ${ }^{[4]}$. Ge Yongbo and Jiang Xuchao have stated that the larger the scale of an enterprise, it is more inclined to use debt financing for financing rather than endogenous financing ${ }^{[5]}$. Lu Zhengfei and Gao Qiang studied the impact of China's capital market system and corporate governance on debt financing ${ }^{[6]}$. There are many studies on debt financing affecting the improvement of social trust, but literatures pertaining to the debt financing of agricultural enterprises are relatively lacking, especially from the perspective of the National Enterprise Credit Information Publicity System after being 
online. Therefore, the debt financing of agricultural enterprises by social credit needs to be further explored. This study uses the data of China's A-shares agricultural companies from 2006 to 2019 and the double difference method to empirically test the impact of the National Enterprise Credit Information Publicity System on the debt financing scale of agricultural companies. A mechanism test has also been conducted in this study. This study found that first, the improvement of the social credit environment can significantly increase the debt financing scale of agricultural enterprises. After the placebo test, the replacement of explained variables, and the control of industry fixed effects, the results obtained are still significant. Second, the mechanism test found that the scale of the enterprise has a complete intermediary effect; that is, the social credit environment can increase the external financing scale of agricultural enterprises by increasing the scale of the enterprises.

\section{Theoretical analysis and research hypothesis}

Social credit has an effect on the contract between different subjects, and eventually, it will have an impact on the investment and financing of enterprises. Debt contracts signed by agricultural enterprises and banks directly affect the debt financing of agricultural enterprises, while commodity contracts signed by agricultural enterprises and other production and operation entities indirectly affect the debt financing of enterprises. Specifically, taking the contracts signed between farmers and agricultural enterprises as an example, based on the theory of incomplete contracts, when social credit is low because farmers themselves are in a weak position, they would lose more in the game with agricultural enterprises. Upon learning relevant information, in order to avoid being "ripped off" by agricultural enterprises after input, certain measures can be taken by farmers to protect themselves. The first is to increase the price of supplies. The measures taken to increase the prices would increase the cost of agricultural enterprises. Production costs reduce the income of production and operation, thereby reducing the willingness of agricultural enterprises to invest and the scale of enterprises. The second is to reduce the supply of products, which directly reduces the production and operation capabilities of agricultural enterprises, resulting in a reduction in the scale of agricultural enterprises. The reduction in the scale of agricultural enterprises will intensify credit discrimination and further reduce the debt financing capacity of agricultural enterprises. When social credit increases, the moral hazard faced by farmers reduces, thus reducing the price of products and increasing the supply of products, which would promote the expansion of investment by agricultural enterprises and increase the scale of enterprises, which is conducive to the increase in value of collateral and to agricultural companies in obtaining debt financing. The product contract signed between the agricultural enterprise and the distributor is the same as the supply contract. When the social credit is low, the asset scale of the agricultural enterprise reduces, and the financing constraints faced by the enterprise increase. The improvement of the credit environment changes this situation, promotes agricultural enterprises to expand production, alleviates credit discrimination, and increases the debt financing capacity of enterprises ${ }^{[5]}$.

(1) Research hypothesis 1: The improvement of social credit increases the debt financing capacity of agricultural enterprises.

(2) Research hypothesis 2: The improvement of social credit promotes the increase of debt financing of agricultural enterprises by expanding the scale of enterprise assets.

\section{Model settings and indicator selection}

\subsection{Source of data and sample processing}

2006-2019 listed agricultural companies have been selected as the research sample. This study uses Guotai An database (CSMAR) to obtain the financial data, which have been processed based on the original data. 
When downloading the data, only agricultural enterprises have been selected. After obtaining the data, according to the characteristics of the data, the samples with missing data have been deleted, obtaining a total of 436 samples. In order to avoid the influence of the maximum and minimum values in the data on debt financing, this study performed a two-way Winsorization on the data at the levels of 1\% and $99 \%$.

\subsection{Measurement model}

This study uses the 2014 National Enterprise Credit Information Publicity System as the impact factor and selects private agricultural enterprises as the research subjects. A double difference method is constructed, and the effect of social credit on the debt financing of agricultural enterprises is explored.

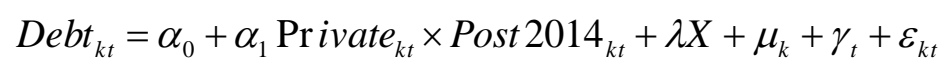

Among them, Debt $k$ represents the debt financing of agricultural enterprise $\mathrm{k}$ in year $\mathrm{t}$, which is standardized by dividing the debt scale by the total assets; Post $2014_{k t}$ represents the impact time of the incident, using the 2014 National Enterprise Credit Information Publicity System as the incident impact. The year is 1 , and it is 0 before 2014. Private $k t$ refers to private enterprises, private enterprises are 1 , and the rest are 0. Using the online National Enterprise Credit Information Publicity System and interactive items of the nature of property rights to construct a double difference to capture the improvement of social credit, where $X$ is the set of control variables, $\mu$ represents the individual fixed effect, and $\gamma$ represents the time fixed effect.

\subsection{Variable definition}

(1) Social credit

Social credit represents an informal environment. In a good social credit environment, the probability of participating in the automatic performance of contracts is greater. This study divides the enterprises into an experimental group and a control group. The experimental group comprises of private enterprises. Since state-owned enterprises and foreign-funded enterprises are better than private enterprises in credit rationing, the improvement of social credit is mainly for private enterprises. The launch of the National Enterprise Credit Information Publicity System platform serves as the dividing line for the improvement of the social credit environment. The interaction between the two (Private $\times$ Post2014) is used as a measure of the social credit environment.

(2) Corporate debt financing

Corporate debt financing is the scale of debt obtained by agricultural enterprises. This article uses the standardization of total assets of the enterprise as a measure of the total debt.

\section{Analysis of the empirical results}

\subsection{Basic regression results}

Table 1 shows the empirical results of the impact of social credit on the debt financing of agricultural enterprises. The research results showed that the coefficient of the interaction term (Private $\times$ Post2014) of the National Enterprise Credit Information Publicity System and the nature of property rights is positive at the $1 \%$ level. After adding the control variables at the enterprise level, the coefficient of the interaction term is still significantly positive, but the absolute value has declined, indicating that the improvement of social credit can increase the debt financing scale of agricultural enterprises, thus supporting the research hypothesis. 
Table 1. Basic regression results

\begin{tabular}{ccc}
\hline & $(1)$ & $(2)$ \\
& Debt & Debt \\
\hline Private $\times$ Post 2014 & $0.0800^{* * *}$ & $0.0592^{* *}$ \\
& $(0.0264)$ & $(0.0230)$ \\
\hline
\end{tabular}

\subsection{Mechanism inspection}

The mechanism to be tested in this study is whether the improvement of social credit will expand the scale of corporate debt financing by expanding the scale of agricultural enterprises' assets. In order to verify the mediating effect of the firm size, this study also needs to design two econometric models.

$$
\begin{gathered}
\text { SIZE }_{k t}=\beta_{0}+\beta_{1}{\text { Pr } \text { ivate }_{k t} \times \text { Post } 2014_{k t}+\lambda X+\mu_{k}+\gamma_{t}+\varepsilon_{k t}}^{\text {Debt }_{k t}=\theta_{0}+\theta_{1} \text { Private }_{k t} \times \text { Post } 2014_{k t}+\theta_{2} \text { SIZE }+\lambda X+\mu_{k}+\gamma_{t}+\varepsilon_{k t}}
\end{gathered}
$$

Table 2 shows the results of the test of the mediation effect of social credit improvement on corporate debt financing. Column (3) shows the impact of social credit improvement and enterprise asset scale on the debt financing of agricultural enterprises. The results showed that the coefficient of the interaction term (Private $\times$ Post2014) has become insignificant, while the coefficient of enterprise asset scale (SIZE) is still significant, indicating that the scale of corporate assets plays a complete intermediary role between social credit and corporate debt financing.

Table 2. Mediating effect test

\begin{tabular}{cccc}
\hline & $(1)$ & $(2)$ & $(3)$ \\
& Debt & SIZE & Debt \\
\hline \multirow{2}{*}{ Private $\times$ Post 2014} & $0.0592^{* *}$ & $0.2933^{* * *}$ & 0.0350 \\
& $(0.0230)$ & $(0.0660)$ & $(0.0235)$ \\
\hline
\end{tabular}

\section{Robustness test}

\subsection{Placebo test}

This study conducts a placebo test on the model by setting the shock time of the false policy. Column (1) of Table 3 shows the regression results after the impact time is pushed back 3 years. Although the coefficient of the interaction term (Private $\times$ Post 2014) is positive, it is not significant, proving that the impact of the online National Enterprise Credit Information Publicity System on the debt financing scale of agricultural enterprises is robust.

\subsection{Replacement of the explained variable measurement index}

Different measurement methods of debt financing may have different effects on the empirical results. In this study, the total debt is standardized by the owner's equity to measure the size of corporate debt financing. The regression results are shown in column (2) of Table 3. The coefficient of the interaction term (Private $\times$ Post 2014 ) is significantly positive at the level of $10 \%$. This result indicates that the results of the basic regression are robust. 
Table 3. Robustness test

\begin{tabular}{ccc}
\hline & $(1)$ & $(2)$ \\
& Debt & Debt $^{1}$ \\
\hline Private $\times$ Post $2014(3)$ & 0.0253 & \\
& $(0.0296)$ & $1.1440^{*}$ \\
Private $\times$ Post 2014 & & $(0.6286)$ \\
\hline
\end{tabular}

\section{Conclusion}

This study uses the data of China's A-shares agricultural companies from 2006 to 2019, dividing private companies (experimental group) from other companies (control group), and using the double difference method to investigate the impact of social credit improvement on the debt financing scale of agricultural companies. The research results showed that first, the improvement of social credit can help increase the debt scale of agricultural enterprises; second, the improvement of social credit does not only directly improve the relationship between agricultural enterprises and banks as well as promote loans, but also reduce credit discrimination by expanding the scale of enterprises, and eventually, obtaining more financing.

\section{Disclosure statement}

The author declares that there is no conflict of interest.

\section{References}

[1] Titman S, Wessels R, 1988, The Determinants of Capital Structure Choice. Journal of Finance, 43(1): $1-19$.

[2] Feng G, Wu L, Liu S, 2000, Analysis of the Influencing Factors of the Capital Structure Formation of Listed Companies in My Country. Economist, 2000(5): 59-66.

[3] Wang H, Qian J, 2021, Major Shareholder Pledge and Debt Financing Cost. Journal of Shanxi University of Finance and Economics, 43(2): 12-18.

[4] Chen X, Sun H, Wang Y, et al., 2021, Media Reputation and Corporate Debt Financing: Evidence Based on Big Data of Media Text Emotion. Journal of Central University of Finance and Economics, 2021(1): 55-60.

[5] Ge Y, Jiang X, 2008, Corporate Financing Behavior and Its Influencing Factors. Financial Research, 335(5): $34-40$.

[6] Lu Z, Gao Q, 2003, Research on the Financing Behavior of Chinese Listed Companies - An Analysis Based on Questionnaire Survey. Accounting Research, 2003(10): 23-28. 